\title{
Surface treatments of ti-alloy based bone implant manufactured by electrical discharge machining'
}

\section{Tratamientos superficiales de aleación de titanio basado en implantes de hueso fabricados por mecanizado de descarga eléctrica ${ }^{2}$}

Nanang Qosim ${ }^{3}$

Sugeng Supriadi ${ }^{4}$

Agung Shamsuddin Saragih ${ }^{5}$

Yudan Whulanza ${ }^{6}$

How to cite this article:

N. Qosim, S. Supriadi, A. Shamsuddin Saragih, Y. Whulanza, "Surface treatments of ti-alloy based bone implant manufactured by electrical discharge machining," Ing. Univ., vol. 22, no. 2, 2018. http s://doi.org/10.11144/Javeriana.iyu22-2.stab

\footnotetext{
${ }^{1}$ Submitted on: November $27^{\text {th }}, 2017$. Accepted on: May $16^{\text {th }}, 2018$.

${ }^{2}$ Fecha de recepción: 27 de Noviembre de 2017. Fecha de aceptación: 16 de Mayo de 2018.

${ }^{3}$ Mechanical engineer. Master in Mechanical Engineering, Universitas Indonesia, Indonesia. E-mail: nanang2307@yahoo.com Corresponding author: Mechanical engineer. Master in Mechanical Engineering, Yeungnam University, Republic of Korea, Ph.D in

${ }^{4}$ Mechanical Engineering, Tokyo Metropolitan University, Japan. Associated Professor in Department of Mechanical Engineering, Faculty of Engineering, Universitas Indonesia, Indonesia. E-mail: sugeng@eng.ui.ac.id

${ }^{5}$ Mechanical engineer. Master in Mechanical Engineering, Yeungnam University, Republic of Korea, Ph.D in Mechanical Engineering, Yeungnam University, Republic of Korea. Associated Professor in Department of Mechanical Engineering, Faculty of Engineering, Universitas Indonesia, Indonesia. E-mail: ashamsuddin@eng.ui.ac.id

${ }^{6}$ Mechanical engineer. Master of Science, RWTH Aachen, Germany. Doctor in Bioengineering, University of Pissa, Italy. Associated Professor in Department of Mechanical Engineering, Faculty of Engineering, Universitas Indonesia, Indonesia. E-mail: yudan@ eng.ui.ac.id
} 


\section{Abstract}

Objective: This research aims to observe the extent to which several surface treatment techniques increase the surface roughness of titanium alloy implants which was manufactured via electrical discharge machining (EDM). The effects of these techniques were also observed to decrease the $\mathrm{Cu}$ content on the implant surface. Materials and Methods: In this research, ultrasonic cleaning, rotary tumbler polishing, and brushing were employed as techniques to increase the roughness of a titanium implant which was manufactured via EDM, to the moderately rough category, and to reduce the contaminant element deposited on its surface. An MTT (3-(4,5dimethylthiazol-2-yl)-2,5-diphenyltetrazolium bromide) assay test was also used to observe the effect of these engineered specimens with respect to mesenchymal stem cells' proliferation. Results and Discussion: The results show that ultrasonic cleaning and rotary tumbler polishing created a significant increase (90\% and $67 \%$, respectively) in the surface roughness. On the other hand, brushing was shown to be the best benchmark for reducing the contamination of Copper $(\mathrm{Cu})$. Furthermore, rotary tumbler polishing and brushing can increase the percentage of living cells compared to the original surface EDM specimens. Conclusion: All micro-finishing methods that were employed are able to increase the surface roughness of Ti alloy based-implant to moderately rough category.

\section{Keywords: Surface roughness; cells} proliferation; Ti-alloy implant; ultrasonic cleaning; rotary tumbler polishing; brushing.

\section{Resumen}

Objetivo: Esta investigación tiene como objetivo observar hasta qué punto varias técnicas de tratamiento de superficies aumentan la rugosidad de la superficie de los implantes de aleación de titanio que se fabricaron a través del mecanizado por descarga eléctrica (EDM). También se observó que los efectos de estas técnicas disminuyen el contenido de cobre en la superficie del implante. Materiales y métodos: En esta investigación, se emplearon la limpieza ultrasónica, el pulido con tambor giratorio y el cepillado como técnicas para aumentar la rugosidad de un implante de titanio que se fabricó a través de EDM, a la categoría moderadamente áspera, y para reducir el elemento contaminante depositado en su superficie. También se utilizó una prueba de ensayo MTT (3-(4,5dimethylthiazol-2-yl)-2,5-diphenyltetrazolium bromide) para observar el efecto de estas muestras modificadas genéticamente con respecto a la proliferación de células madre mesenquimáticas. Resultados y discusión: Los resultados muestran que la limpieza con ultrasonidos y el pulido con tambor giratorio crearon un aumento significativo ( $90 \%$ y $67 \%$, respectivamente) en la rugosidad de la superficie. Por otro lado, se demostró que el cepillado es el mejor punto de referencia para reducir la contaminación del cobre $(\mathrm{Cu})$. Además, el pulido y cepillado de la secadora giratoria puede aumentar el porcentaje de células vivas en comparación con las muestras de EDM de superficie originales. Conclusión: todos los métodos de microacabado que se emplearon pueden aumentar la rugosidad de la superficie de los implantes basados en aleaciones de Titanio a la categoría de rugosidad moderada.

Palabras clave: Rugosidad de la superficie; proliferación de células; Implante de aleación de Titanio; limpieza ultrasónica; pulidor de tambor rotativo; cepillado. 


\section{Introduction}

There are two types of response after implantation. The first type involves the formation of a fibrous soft tissue capsule around the implant. This fibrous tissue capsule does not ensure proper biomechanical fixation and leads to clinical failure of the implant. The second type of bone response is related to direct bone-implant contact (BIC) without an intervening connective tissue layer. This is known as osseointegration. The rate and quality of osseointegration in titanium implants are related to their surface properties. Surface composition, hydrophilicity, and roughness are parameters that may play a role in implant-tissue interaction and osseointegration [1].

Recently, many works have been carried out on surface treated commercial titanium implants to enhance the osseointegration function. By increasing the surface roughness, an increase in the osseointegration rate and the biomechanical fixation of titanium implants have been observed [2]. The surface roughness of the implant plays a vital role in influencing the higher BIC values. High BIC values determine the success of implant osseointegration. Macrophages and osteoblasts exhibit a tendency to attach to rougher surfaces rather than to smooth surfaces, such as on implants manufactured by the machining process $[3,4]$.

Many experimental investigations [1,5-9] have demonstrated that the implant surface topography influenced the bone response; smooth $(\mathrm{Ra}<0.5 \mu \mathrm{m})$ and minimally rough $(\mathrm{Ra} 0.5-1 \mu \mathrm{m})$ surfaces showed weaker bone responses than rougher surfaces. Moderately rough $(\operatorname{Ra} 1-2 \mu \mathrm{m})$ surfaces showed stronger bone responses than rough surfaces $(\mathrm{Ra}>2 \mu \mathrm{m})$.

One crucial problem in the fabrication of an implant using EDM machines is the deposition of contaminant element on the surface of the implant, which is caused by the use of the electrode. Undeniably, copper is one of the most widely used materials for EDM electrodes that are used to fabricate titanium and its alloys [10]. Unfortunately, copper has a detrimental effect on the application the application of EDM electrodes in the field of surgery. An excess of copper can lead to cytotoxicity in a cell [11].

In this study, to observe the cytotoxic effect of $\mathrm{Cu}$ on the engineered specimens, the MTT assay was performed to identify the effect of copper onto cells' proliferation. Rubianto [12] proposed that the benchmark of a good biocompatibility is $92.3 \%-100 \%$ survival of living cells. This value is higher than the benchmark proposed by Telli et al. [13], whose research suggested that toxicity parameters are based on CD50, meaning that a substance is toxic if the percentage of living cells after exposure to the material is less than $50 \%$.

This research aims to observe the extent to which several techniques, including ultrasonic cleaning, rotary tumbler polishing, and brushing, increase the surface roughness of titanium alloy implants manufactured by EDM. The final surface roughness values that can be achieved by EDM are in the range of $0.25-0.8 \mu \mathrm{m}$ [14]. Afterward, the effects of these techniques were also observed to decrease the copper $(\mathrm{Cu})$ content on the implant surface. A validation by biological analysis was also performed to observe the cells' proliferation on surfaces engineered by these techniques. 


\section{Materials and methods}

\subsection{Material Preparation}

In this research, all investigations are conducted using a Ti-6Al-4V titanium alloy. The specimens engineered herein are the prototype of a miniplate-shaped implant that was developed in our previous work, as shown in Fig. [15]. Afterwards, the surface treatments are employed to determine the surface roughness of specimens by using several techniques. Five specimens are engineered for each technique. The first method is polishing by a steel brush. The specimens were mechanically polished for 30 minutes. The second method is an ultrasonic cleaning process. $\mathrm{Al}_{2} \mathrm{O}_{3}$ is added to take effect on specimen surface roughness. Specimens were cleaned on a Digital Ultrasonic Cleaner for 4 hours. The last treatment is using a rotary tumbler polisher, KT 6808, Kyngty, China. Sintered $\mathrm{Al}_{2} \mathrm{O}_{3}$ is used as polisher balls. This process was run for 8 hours. These methods were chosen because they are inexpensive techniques of implant surface treatment that can provide significant results.

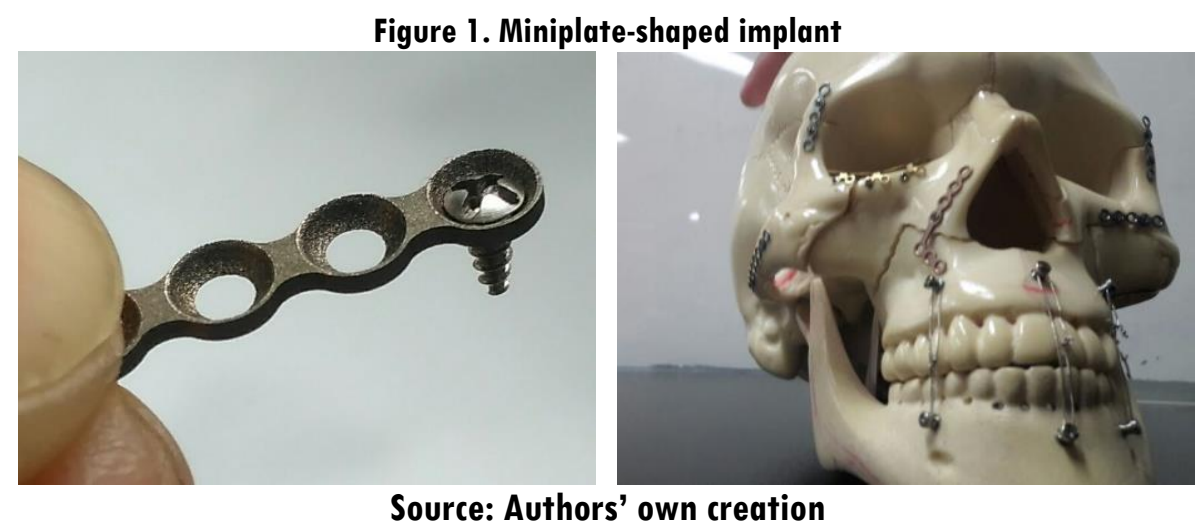

\subsection{Surface Roughness}

The surface roughness of specimens was evaluated by using Surfcom 2900SD3 series, Tokyo Seimitzu, Japan. There were two essential parameters of surface roughness observed. Rmax is the difference between the highest and lowest point of the profile in the evaluated region. Ra is average deviation of the roughness profile from the mean line below:

$R a=\frac{1}{n} \sum_{i=1}^{n}\left|y_{i}\right|$

Like the other measurement instruments, the first procedure is the calibration process. Then, the necessary parameters are adjusted, such as measurement length, motion speed, units, and so on, followed by setting the workpiece to determine its zero point. Finally, the surface roughness measurement can be performed. In this study, the measurement length observed is $4 \mathrm{~mm}$. 


\subsection{SEM-EDS Observations}

Topography observation is performed by using Quanta 650, FEI, Oregon, USA, a scanning electron microscope (SEM) at an accelerating voltage of $10 \mathrm{kV}$. The area observed is the strut bar, the center-top surface of the specimen. This observation then followed by energy dispersive spectroscopy (EDS) observation by using Oxford Instruments. This is done to observe the reduction of $\mathrm{Cu}$ content on the surface of the implants.

\subsection{Biological Evaluation}

The specimens engineered are expected to have surfaces that do not contain harmful contaminant elements which may act against cells and tissues. Cytotoxic tests by indirect contact with MTT (3(4,5-dimethylthiazol-2-yl)-2,5-diphenyltetrazolium bromide) tetrazolium reduction assay was performed to evaluate their respective biological effects.

The first step is culturing the mesenchymal stem cell (MSC) as described by Rahyussalim, et al. [16]. Mesenchymal stem cells (MSCs) were isolated from human lipid tissue and have been preserved by cryopreservation technique. Cells were seeded into a T25 flask with the density of 5000 cells $/ \mathrm{cm}^{2}$. Five $\mathrm{mL}$ complete medium was added to the flask. Flasks were then incubated at

$37^{\circ} \mathrm{C}$ and $5 \% \mathrm{CO}_{2}$ and observed daily. Every 2-3 days, the media were replaced until mesenchymal stem cells were $90 \%$ confluent, and ready for harvesting [17].

In the MTT assay, specimens and cultured cells are tested with Vybrant ${ }^{\circledR}$, and the absorbance value was determined by an ELISA reader at a wave length of $570 \mathrm{~nm}$. This assay measures cellular metabolic activity via $\mathrm{NAD}(\mathrm{P}) \mathrm{H}$-dependent cellular oxidoreductase enzymes and may, under defined conditions, reflect the number of viable cells (cell proliferation). The specimens were incubated in alpha-MEM (Gibco, USA) along with the MSCs and mediums. As much as $10 \mu \mathrm{L}$ MTT reagent was added to each well and incubated for 4 hours at $37^{\circ} \mathrm{C}$. Right after formazan crystals were clearly identified, $100 \mu \mathrm{L}$ SDS $10 \%$ in $0.1 \mathrm{~N} \mathrm{HCl}$ (stopper) was added. Cells and media without a specimen were observed as the control.

\section{Results and Discussion}

\subsection{Surface Roughness}

Surface roughness was measured for different types of specimens, and the results are summarized in Fig. 2. Benchmark EDM + ultrasonic cleaning specimens proved to have the highest Ra. This method significantly increased the original roughness achieved by the previous EDM process. Furthermore, it also showed the highest percentage of roughness increase, approximately $90 \%$.

Benchmark rotary tumbler polishing specimens also showed an excellent increase in surface roughness. On the other hand, benchmark polishing specimens could not increase the surface roughness of specimens. There were even some specimens that experienced a decrease in surface roughness. 
Figure 2. Surface Micro Roughness: (a) original EDM; (b) after rotary tumbler polishing; (c) after ultrasonic cleaning; and (d) after brushing process
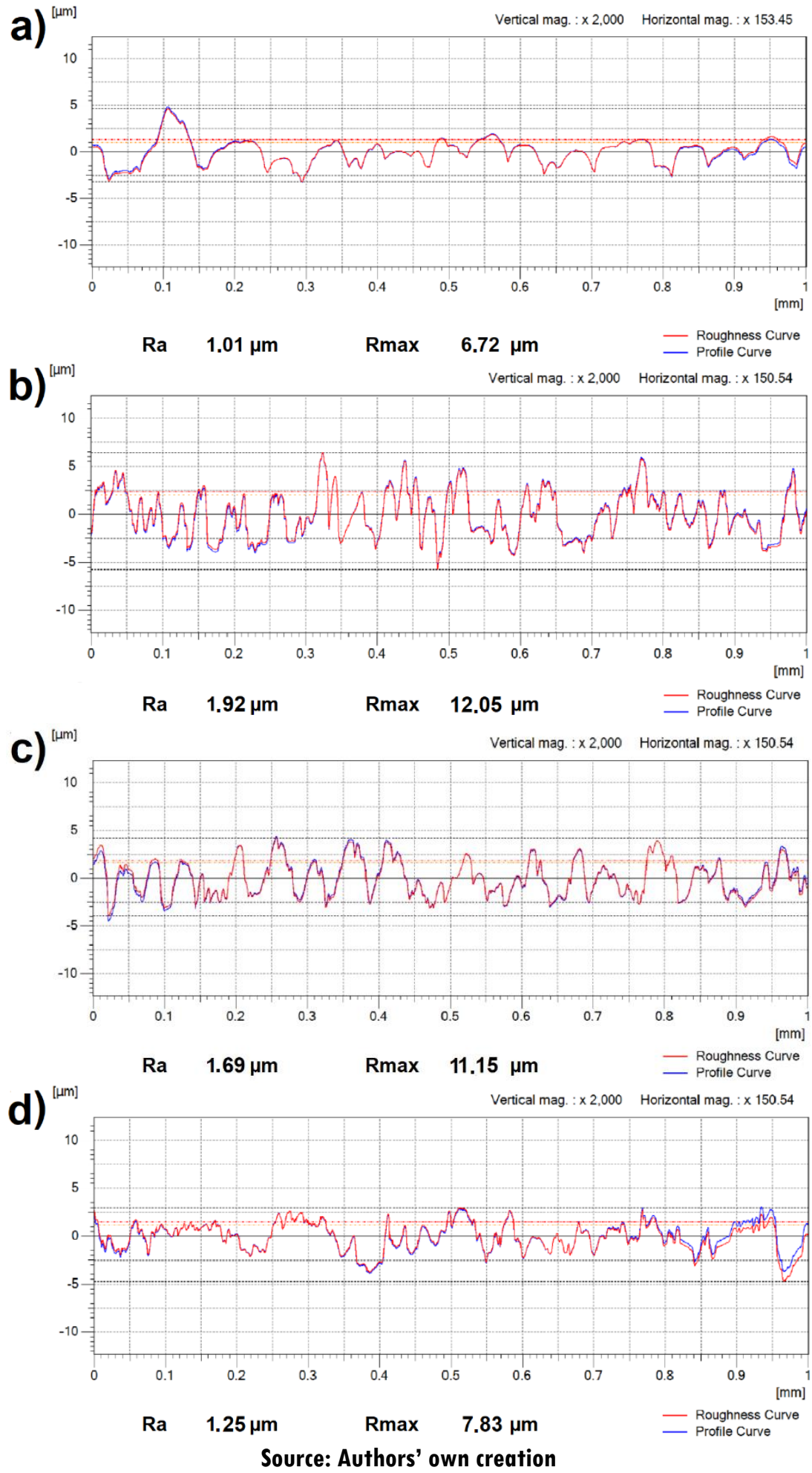
As the easiest and fastest method used to acquire good surface roughness required for implantation, ultrasonic cleaning is recommended as an effective method for surface characterization. In addition, this method can clean debris and contaminants on the implant surface.

\subsection{SEM-EDS Observations}

All benchmarks of surface treatments were subjected to SEM observations. Micrographs are depicted in magnification at 500x. Fig. 3 shows a the comparison of the surface micrographs after several processes. Fig. 3a shows the surface micrographs of the original EDM specimens. Quantitatively, this surface has a roughness of $1.01 \mu \mathrm{m}$. Fig. $3 \mathrm{~b}$ and $3 \mathrm{c}$ show the specimen surfaces after rotary tumbler polishing and ultrasonic cleaning processes. These processes severely damaged the material. Drops of resolidified metal, debris and craters are highly visible. Sintered-A12O3 used in these methods successfully increased the roughness of the specimen surface to moderately rough. Visually, we can conclude that these surfaces have a higher surface roughness than achieved by the original EDM and brushing process. A micrograph of the specimen surface after brushing is depicted in Fig. 3d. It appears that the specimen surface is much smoother compared to the surfaces treated with ultrasonic cleaning and rotary tumbler polishing. This process was able to scrape debris and block $\mathrm{Cu}$ contamination from the surface of the specimen. 
Figure 3. The comparison of micrographs of the surface. (a) original EDM; (b) after rotary tumbler polishing; (c) after ultrasonic cleaning; and (d) after brushing process

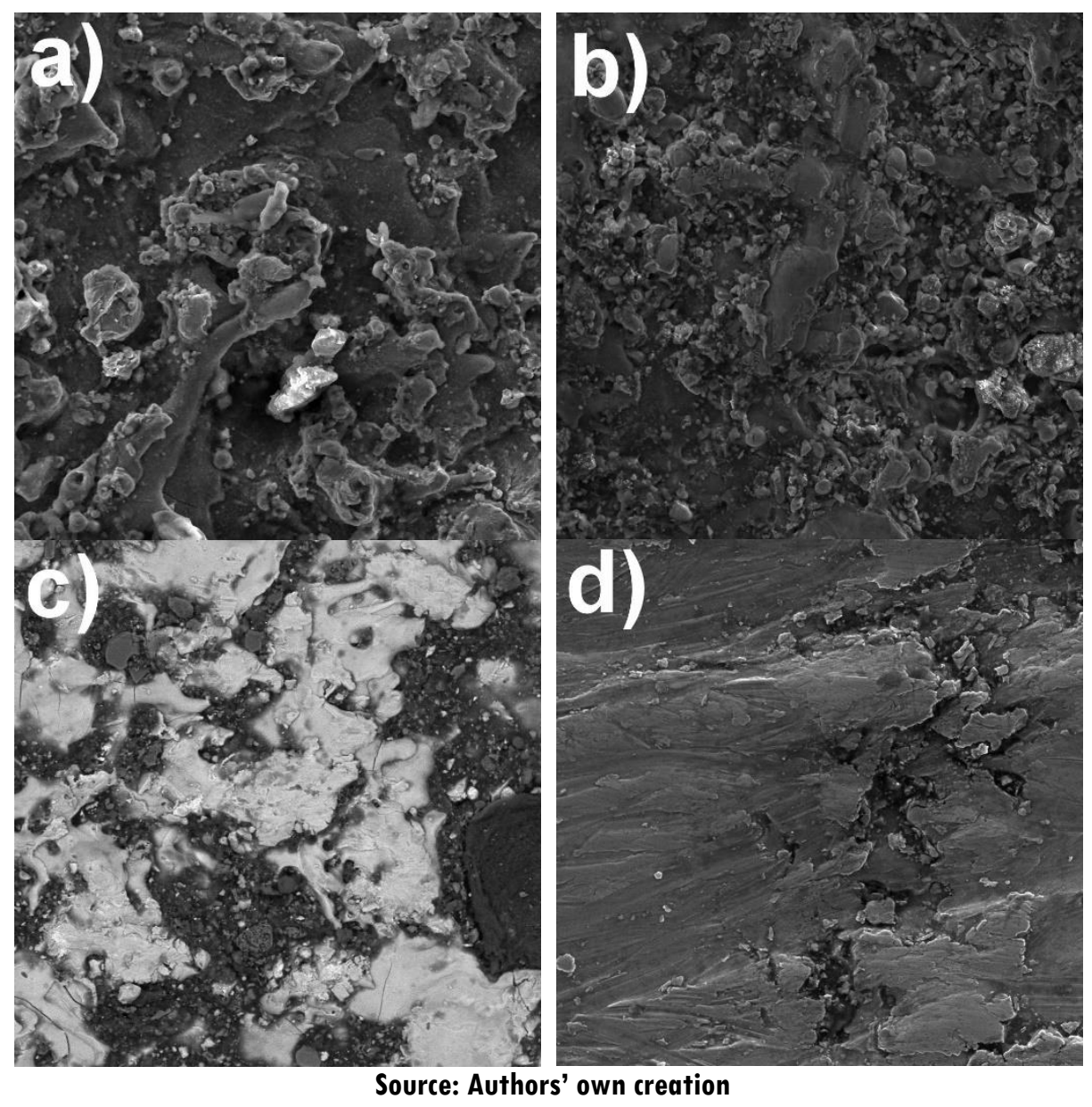

Fig. 3 shows that there are lighter debris than the others. Using EDS analysis, these sections are identified as $\mathrm{Cu}$ which has a higher atomic number. As shown in Fig. 4.a, the level of $\mathrm{Cu}$ on the original surface of EDM is very high. This is due to the $\mathrm{Cu}$-wire used during the wire-cutting process which forms the outer profile of miniplate, as well as its use during the slicing process to divide the specimen into several pieces. 
Figure 4. The comparison of EDS results (red arrows indicate the spectrum of areas analyzed): (a) original EDM; (b) after rotary tumbler polishing; (c) after ultrasonic cleaning; and (d) after brushing process
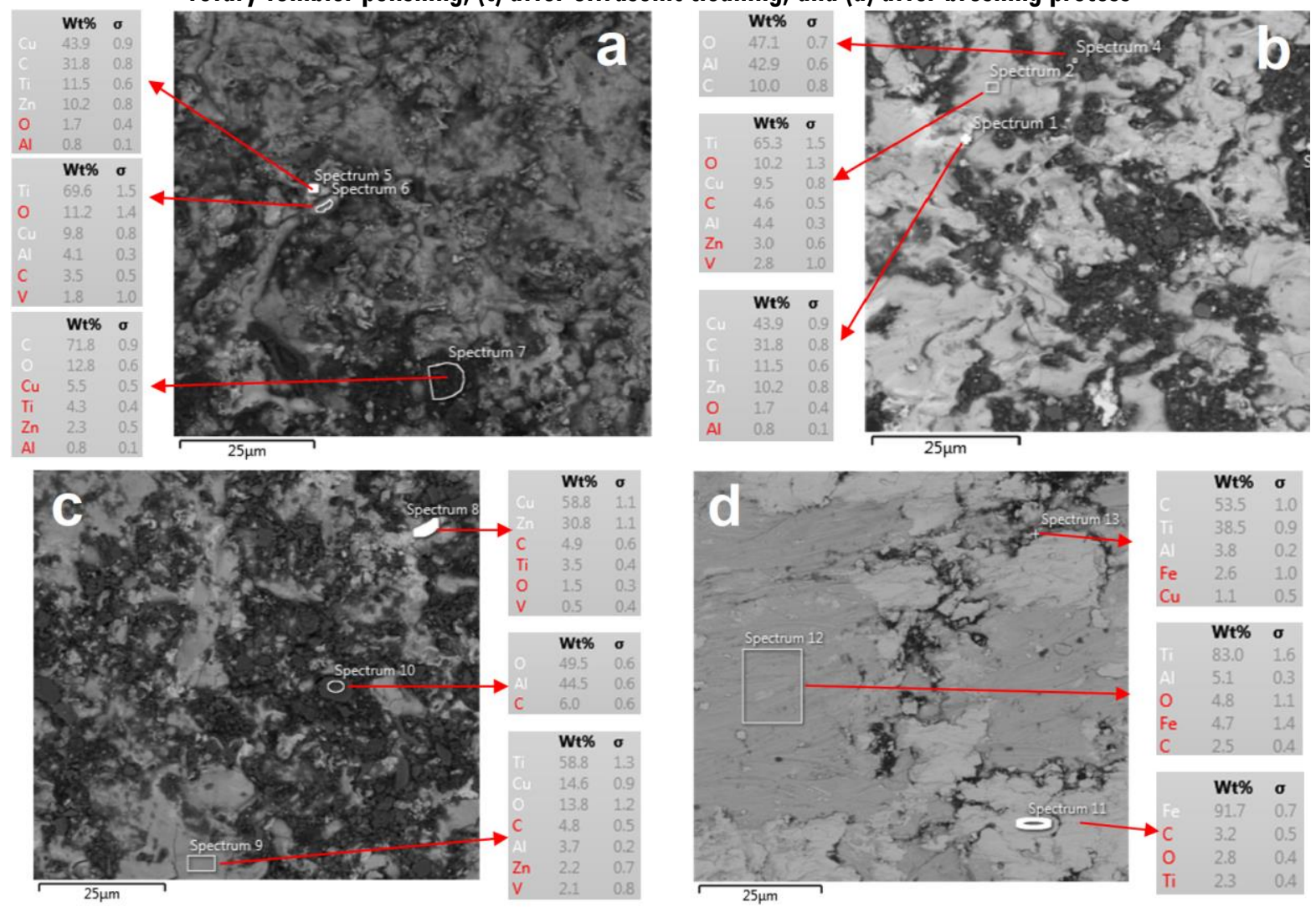

Source: Authors' own creation

The EDS results for the specimen surface after rotary tumbler polishing (Fig. 4.b) show that there is no significant decrease in the contamination of $\mathrm{Cu}$ on the specimen surface. It is clear that this treatment could not remove the $\mathrm{Cu}$ from the specimen surface. Fig. 4.c shows the results of the EDS analysis for benchmark ultrasonic cleaning. The result is almost identical to the benchmark rotary tumbler polishing. There is no significant decrease in the contamination on the surface of the specimen, but the percentage of reduction is slightly less than that of the rotary tumbler polishing process. EDS results of benchmark brushing, as shown in Fig. 4.d, show that the level of $\mathrm{Cu}$ on the surface of the specimen is almost $0 \%$. With longer brushing time, this process is more suitable for smoothing out the roughness to obtain the minimally rough $(<0.1 \mu \mathrm{m})$ roughness category. These results will be validated by biological analysis.

\subsection{Biological Analysis}

As described in the background of this study, the surface of an implant is required to be non-toxic and non-irritating to surrounding biological tissues. To meet this requirement, a cytotoxic test was conducted as a biological evaluation of the implant prototype produced. In this study, a cytotoxic test was performed by the MTT assay and the results are shown in Fig. 5. 


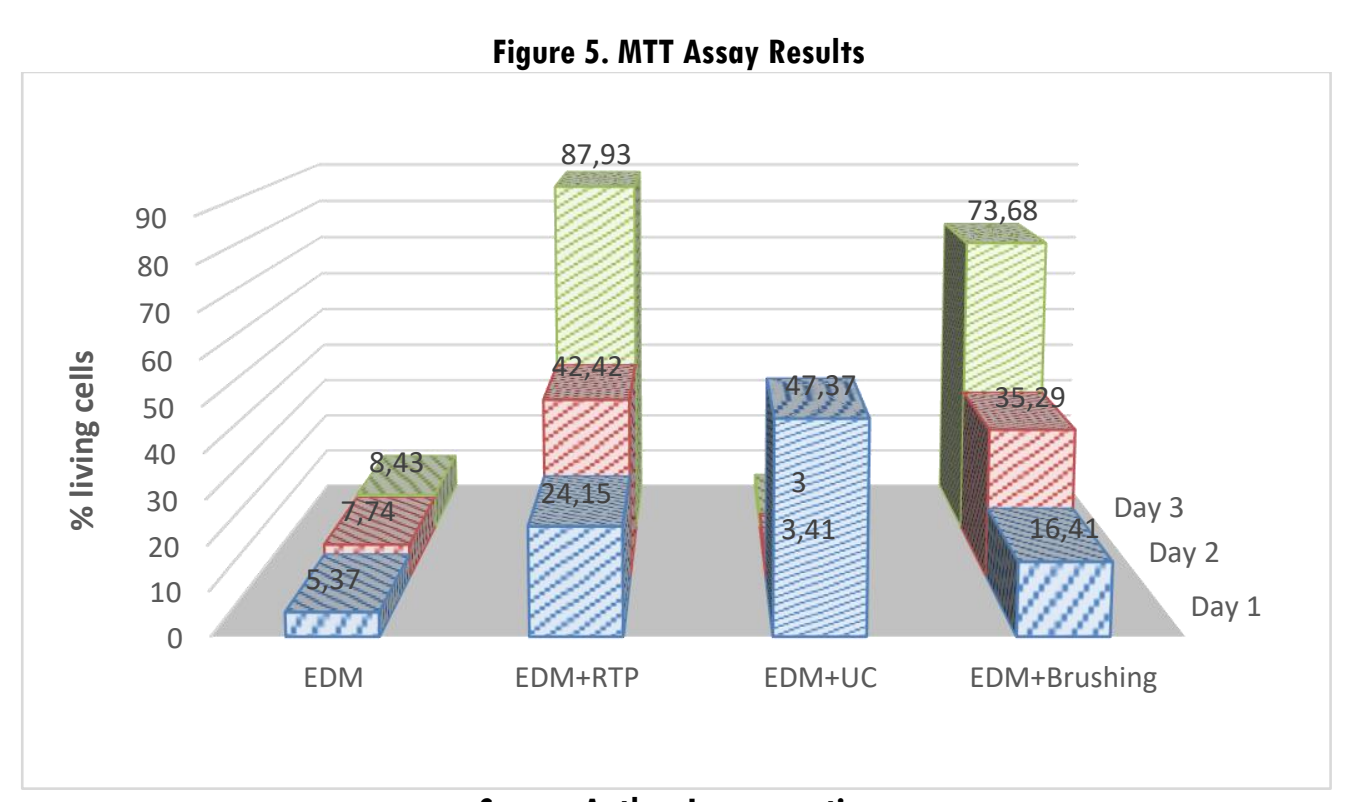

Source: Authors' own creation

From the graph in Fig. 5, it can be interpreted that specimens engineered by the methods of rotary tumbler polishing, mechanical brushing, and ultrasonic cleaning exhibit varying effects on the viability and proliferation of mesenchymal stem cells (MSCs). The benchmark rotary tumbler polishing inhibits proliferation and viability of MSCs on day-1 and day 2 . This is characterized by the percentage of living cells below 50\%. However, on day 3 after planting with MSCs, there is a significant increase with the highest living cell percentage of $87.93 \%$. The specimens engineered by ultrasonic cleaning, identified as having the highest contaminant $\mathrm{wt} \% \mathrm{Cu}$, inhibit the viability and proliferation of MSCs between day 1 and 3 with the lowest living cells percentage $(3.41 \%)$. This proves the toxic effect of $\mathrm{Cu}$ on cells and biological tissues in the human body $[11,18,19]$.

On the other hand, the specimens engineered by the mechanical brushing method, on days 1 and 2 , show a low percentage of living cells $(<50 \%)$, although EDS observations showed that wt $\% \mathrm{Cu}$ on the surface is $0 \%$. This finding is probably due to the iron (Fe) deposited on its surface with a wt $\%$ 4.7, which resulted from the use of a steel brush. As mentioned by Tapiero, et al. [11], Fe may also lead to cytotoxicity, like $\mathrm{Cu}$. Thus, the deposits of Fe on the specimen surface may inhibit the viability and proliferation of MSCs.

Overall, with the exception of ultrasonic cleaning methods, all of the surface treatments conducted can increase the percentage of living cells compared to the original EDM specimens.

\section{Conclusions}

In the present study, different methods of surface micro-finishing are employed. The conclusion drawn from the experimental study is as follows:

1. Ultrasonic cleaning and rotary tumbler polishing techniques with added sintered- $\mathrm{Al}_{2} \mathrm{O}_{3}$ provided significant results of surface roughness increase with a percentage increase of $90 \%$ and $67 \%$, respectively, from the original EDM. 
2. While the brushing technique did not provide significant changes to the increase in surface roughness of the specimen, it was almost entirely capable of removing contamination of $\mathrm{Cu}$ element on the surface of the implant compared to the other methods.

3. Rotary tumbler polishing and brushing can increase the percentage of living cells compared to the original EDM specimens.

4. Future research is expected to combine some of these techniques to acquire a surface roughness in the moderately rough category ( $\mathrm{Ra} 1-2 \mu \mathrm{m}$ ) while also significantly removing the reducing the level of $\mathrm{Cu}$ from the surface of the implants manufactured by EDM.

\section{Acknowledgments}

The authors would like to thank LPDP (Indonesian Endowment Fund for Education), Ministry of Finance, Republic of Indonesia, for scholarship funding “Beasiswa Pendidikan Indonesia LPDP”.

\section{References}

[1] L. Le Guéhennec, A. Soueidan, P. Layrolle, and Y. Amouriq, "Surface treatments of titanium dental implants for rapid osseointegration," Dental Materials, vol. 23, no. 7, pp. 844-854, 2007. [Online]. Available: https://doi.org/10.1016/j.dental.2006.06.025

[2] A. Jemat, M. J. Ghazali, M. Razali, and Y. Otsuka, "Surface modifications and their effects on titanium dental implants," BioMed Res Int, vol. 2015, 2015. [Online]. Available: http://dx.doi.org/10.1155/2015/791725

[3] J. Gallo, M. Holinka, and C. S. Moucha, "Antibacterial surface treatment for orthopaedic implants," Int J Mol Sci, vol. 15, no. 8, pp. 13849-13880, Aug 2014. [Online]. Available: https://dx.doi.org/10.3390\%2Fijms 150813849

[4] B. Chehroudi, S. Ghrebi, H. Murakami, J. D. Waterfield, G. Owen, and D. M. Brunette, "Bone formation on rough, but not polished, subcutaneously implanted Ti surfaces is preceded by macrophage accumulation," $J$ Biomed Mater Res A, vol. 93, no. 2, pp. 724-737, May 2010. [Online]. Available: https://doi.org/10.1002/jbm.a.32587

[5] A. Wennerberg and T. Albrektsson, "Effects of titanium surface topography on bone integration: a systematic review," Clin Oral Implants Res, vol. 20, no. 4, pp. 172-184, Sep 2009. [Online]. Available: https://doi.org/10.1111/j.1600-0501.2009.01775.x

[6] K. Vandamme, I. Naert, J. Vander Sloten, R. Puers, and J. Duyck, "Effect of implant surface roughness and loading on peri-implant bone formation," J Periodontol, vol. 79, no. 1, pp. 150-157, Jan 2007. [Online]. Available: https://doi.org/10.1902/jop.2008.060413

[7] S. Grassi, A. Piattelli, L. C. de Figueiredo, M. Feres, L. de Melo, G. Iezzi, et al., "Histologic evaluation of early human bone response to different implant surfaces," J Periodontol, vol. 77, no. 10, pp. 1736-1743, Oct 2006. [Online]. Available: Histologic evaluation of early human bone response to different implant surfaces

[8] J. E. Ellingsen, C. B. Johansson, A. Wennerberg, and A. Holmén, "Improved retention and bone-to-implant contact with fluoride-modified titanium implants," Int J Oral Maxillofac Implants, vol. 19, no. 5, Sep-Oct 2004.

[9] Y. T. Sul, B. S. Kang, C. Johansson, H. S. Um, C. J. Park, and T. Albrektsson, "The roles of surface chemistry and topography in the strength and rate of osseointegration of titanium implants in bone," J Biomed Mater Res A, vol. 89, no. 4, pp. 942-950, Jun 2009. [Online]. Available: https://doi.org/10.1002/jbm.a.32041

[10] A. Hasçalık and U. Çaydaş, "Electrical discharge machining of titanium alloy (Ti-6Al-4V)," Appl Surf Sci, vol. 253, no. 22, pp. 9007-9016, Sep 2007. [Online]. Available: https://doi.org/10.1016/j.apsusc.2007.05.031

[11] H. Tapiero, D. W. Townsend, and K. D. Tew, "Trace elements in human physiology and pathology. Copper," Biomed Pharmacotherapy, vol. 57, no. 9, pp. 386-398, Nov 2003. [Online]. Available: https://doi.org/10.1016/S0753-3322(03)00012-X

[12] M. Rubianto, "Biokompatibilitas bahan allograft (human bone powder) dibandingkan dengan bahan alloplast (hydroxylapatite)," Kumpulan naskah Temu Ilmiah Nasional I (TIMNAS I) FKG UNAIR, pp. 507-9, 1998. 
[13] C. Telli, A. Serper, A. L. Dogan, and D. Guc, "Evaluation of the cytotoxicity of calcium phosphate root canal sealers by MTT assay," J Endodontics, vol. 25, no. 2, pp. 811-813, Dec 1999. [Online]. Available: https://doi.org/10.1016/S0099-2399(99)80303-3

[14]E. C. Jameson, Electrical discharge machining: Society of Manufacturing Engineers, 2001.

[15] N. Qosim, S. Supriadi, Y. Whulanza, and A. Saragih, "Development of Ti-6al-4v Based-Miniplate Manufactured by Electrical Discharge Machining as Maxillofacial Implant," J Fund Appl Sci, vol. 10, pp. 765-775, 2018.

[16] J. Rahyussalim, T. Kurniawati, D. Aprilya, R. Anggraini, G. Ramahdita, and Y. Whulanza, "Toxicity and biocompatibility profile of 3D bone scaffold developed by Universitas Indonesia: A preliminary study," in AIP Conf 1817, 2017. [Online]. Available: https://doi.org/10.1063/1.4976756

[17] A. F. Kamal, D. Iskandriati, I. H. Dilogo, N. C. Siregar, E. U. Hutagalung, R. Susworo, et al., "Biocompatibility of various hydoxyapatite scaffolds evaluated by proliferation of rat's bone marrow mesenchymal stem cells: an in vitro study," MJI, vol. 22, no. 4, p. 202-208, 2013. [Online]. Available: https://doi.org/10.13181/mji.v22i4.600

[18] R. P. Singh, S. Kumar, R. Nada, and R. Prasad, "Evaluation of copper toxicity in isolated human peripheral blood mononuclear cells and it's attenuation by zinc: ex vivo," Mol Cell Biochem, vol. 282, no. 1-2, pp. 13-21, Jan 2006. [Online]. Available: https://doi.org/10.1007/s11010-006-1168-2

[19] N. Aston, N. Watt, I. Morton, M. Tanner, and G. Evans, "Copper toxicity affects proliferation and viability of human hepatoma cells (HepG2 line)," Hum Exp Toxicol, vol. 19, no. 6, pp. 367-376, Jun 2000. [Online]. Available: https://doi.org/10.1191/096032700678815963 